\title{
Effect of Different Dates of Sowing on the Incidence of Pigeonpea Gall Weevil Alcidodes collaris (Pascoe)
}

\author{
T.N. Rakshitha*, Subhash Kandakoor, M.G. Hegde and Ganajaxi Math \\ Department of Agricultural Entomology, UAS, Dharwad-580005, Karnataka, India \\ *Corresponding author:
}

\section{A B S T R A C T}

\section{Keywords}

Gall weevil, Incidence, Pigeonpea

Article Info

Accepted:

20 May 2019

Available Online:

10 June 2019
Pigeonpea is an important pulse crop is known to attack by wide range of insect pests from seedling stage to storage. Among these, recently gall weevil causing threat to pigeonpea at seedling stage. Results revealed that pigeonpea late sown crop will suffer much with more than 73.30 percent damage and the early sown crop escapes with only 30 percent damage at 30 DAS. The rainfall and minimum temperature showed negative correlation(-0.344, -0.330 with minimum temperature at 20 and $30 \mathrm{DAS},-0.658,-0.580$ with rainfall at 20 and $30 \mathrm{DAS}$ ) Also, the damaged plant showed least number of branches (1.6 branches) and plant height $(66.3 \mathrm{~cm})$ compared to healthy plants.

\section{Introduction}

Pigeonpea [Cajanus cajan (L.) Millsp.] is an important multipurpose grain legume, perennial shrub, 1-4m tall, generally grown in tropics and subtropics. The pigeonpea is known to attack by a wide range of insect pests both in the field (at various stages of crop growth) and storage. Insects consume and damages almost all parts of the pigeonpea plant (Upadhyay et al., 1998).

From last few decades gall weevil Alcidodes collaris (Pascoe) is becoming an important culprit in the seedling stage and also vegetative stage of the crop grown especially in the northern transitional belt of Karnataka causing 25-30 per cent reduction in plant population. It attacks the basal region of seedlings and resulting in the formation of galls at the collar region leads to dislodging and drying of plants (Parchabhavi et al., 1972; Rachappa and Lingappa, 2006). Adult nibbles the seedling at growing tips at later stages leads to drooping of young tips.

Pigeonpea gall weevil Alcidodes collaris belongs to the subfamily Alcidinae of family Curculionidae and order Coleoptera. Medium sized body with brown pronotum, creamish spots on the black elytra, geniculate antenna and 4 segmented tarsi are the taxonomic characteristics of pigeonpea gall weevil. The gall weevil damages 15 to 30 days old plants 
by scraping the basal portion of the stem for egg laying. After hatching, grubs feeds on internal tissues of the stem leads to gall formation at the collar region finally dislodging and drying of the plant occurs (Hugar, 2001).

Since the pest inhabits in the soil near the basal portion of stem, makes difficult for its prediction of infestation, distribution and damage. It is very important to know the stage and time of occurrence of gall weevil which helps in effective control of the pest. Keeping these points an experiment was conducted to study the effect of different dates of sowing on the incidence of gall weevil and yield parameters.

\section{Materials and Methods}

The field experiment was carried out to study the incidence of gall weevil in pigeonpea with different dates of sowing at 10 days of interval from July $1^{\text {st }}$ week to August. Pigeonpea variety TS-3R was sown at Main Agricultural Research Station, Dharwad with the plot size of $5 \mathrm{~m} \times 3 \mathrm{~m}$ and spacing of 90 $\mathrm{cm} \times 30 \mathrm{~cm}$.

The recommended package of practices carried out except plant protection measures at vegetative stage of the crop.

At 10 days after crop emergence the following observations recorded from 6 date of sowings using randomly selected 10 plants from each plot. In each plot, total number of galled and healthy plants were counted at 20 and 30 days after crop emergence and expressed as per cent gall formed plants. The observations on the incidence of gall weevil was expressed in per cent by using the formula,

Per cent galled plants $=$ Galled plants $/$ Total Number of plants observed $* 100$
The dried and dislodged plants were observed till the harvest of the crop. Number of branches, plant height and yield was recorded in both healthy and damaged plants. The density of pest population was correlated with weather parameters like maximum and minimum temperature, relative humidity and rainfall to know the impact of various abiotic factors on the incidence of gall weevil and statistically analyzed.

\section{Results and Discussion}

The results clearly indicated that, the damage by the gall weevil increased with delayed sowing. The observation was made at 20 DAS and 30 DAS. The July $1^{\text {st }}$ fortnight sown crop showed only 23 percent incidence and incidence gradually increased to $26.60,40$, $40.30,46.60$ and 60 per cent in the subsequent sowing dates with 10 days of intervals, after 20 days of sowing. The same trend followed in 30 days after sowing. But, the incidence increased slowly in all the dates of sowing with 30 per cent incidence in July first fortnight sown crop and gradually increased to $36.60,46.60,53.30,56.00$ and 73.30 per cent in subsequent sowing dates (Table 1).

The incidence data was subjected to the weather parameters (Table 2). The correlation analysis revealed that minimum temperature and rainfall have a negative influence on the incidence of pest $(-0.344$ and -0.650 respectively).

The relationship was significant in case of maximum temperature and relative humidity showed positive correlation ( 0.441 and 0.387 respectively) at 20 DAS of the crop.

The similar trend followed even at 30 DAS with -0.330 and -0.580 for minimum temperature and rainfall respectively and $0.365 \& 0.298$ for maximum temperature and relative humidity respectively. 
The gall weevil impact was assessed by observing plant height, number of branches and yield in healthy and damaged plants (Fig. 1). In early sown crop the plant height was $155.3 \mathrm{~cm}$ in healthy plant, $128.5 \mathrm{~cm}$ in damaged plant, 6.3 branches /plant in healthy and only 3.3 branches in damaged plants. Accordingly yield also varied with $24 \mathrm{q} / \mathrm{ha}$ in healthy plant and $14.67 \mathrm{q} / \mathrm{ha}$ in damaged plants.

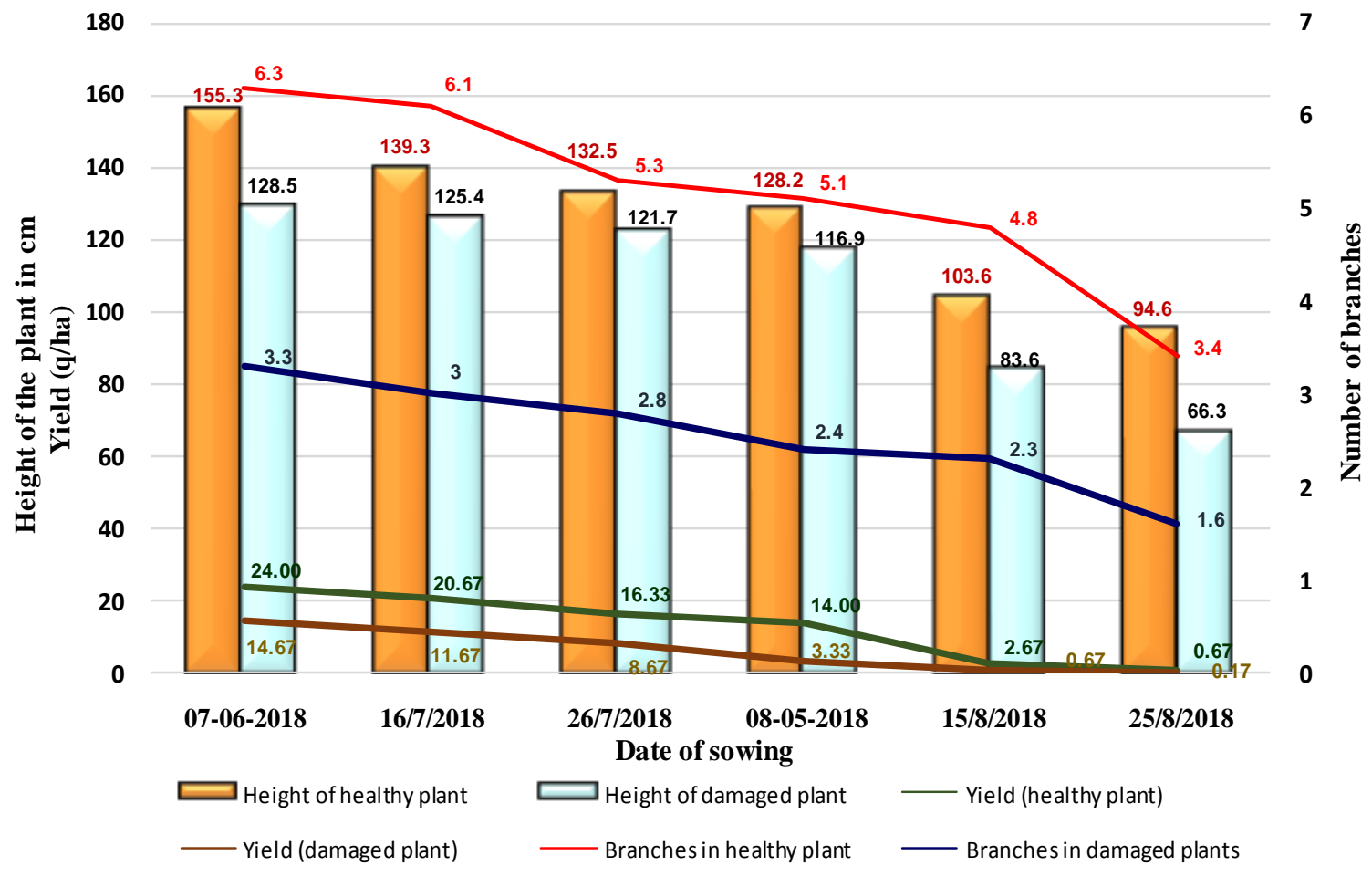

Fig. 1: Influence of gall weevil on plant height, number of branches and yield

Table.1 Incidence of gall weevil with different dates of sowing

\begin{tabular}{|l|l|l|l|l|l|l|}
\hline \multirow{2}{*}{$\begin{array}{c}\text { Date of } \\
\text { sowing }\end{array}$} & \multicolumn{2}{|c|}{ Observation at 20 Days after sowing } & \multicolumn{3}{|c|}{ Observation at 30 Days after sowing } \\
\cline { 3 - 8 } & Date & $\begin{array}{l}\text { No. of } \\
\text { galled } \\
\text { plants }\end{array}$ & $\begin{array}{l}\text { Incidence } \\
\text { of gall } \\
\text { weevil (\%) }\end{array}$ & Date & $\begin{array}{l}\text { No. of } \\
\text { galled } \\
\text { plants }\end{array}$ & $\begin{array}{l}\text { Incidence } \\
\text { of gall } \\
\text { weevil (\%) }\end{array}$ \\
\hline $\mathbf{6 / 7 / 2 0 1 8}$ & $26 / 7 / 2018$ & 2.30 & 23.00 & $5 / 8 / 2018$ & 3.00 & 30.00 \\
\hline $\mathbf{1 6 / 7 / 2 0 1 8}$ & $5 / 8 / 2018$ & 2.66 & 26.60 & $15 / 08 / 2018$ & 3.66 & 36.60 \\
\hline $\mathbf{2 6 / 7 / 2 0 1 8}$ & $15 / 8 / 2018$ & 4.00 & 40.00 & $25 / 08 / 2018$ & 4.66 & 46.60 \\
\hline $\mathbf{5 / 8 / 2 0 1 8}$ & $25 / 8 / 2018$ & 4.33 & 43.30 & $4 / 9 / 2018$ & 5.33 & 53.30 \\
\hline $\mathbf{1 5 / 8 / 2 0 1 8}$ & $4 / 8 / 2018$ & 4.66 & 46.60 & $14 / 9 / 2018$ & 5.60 & 56.00 \\
\hline $\mathbf{2 5 / 8 / 2 0 1 8}$ & $14 / 8 / 2018$ & 6.00 & 60.00 & $24 / 9 / 2018$ & 7.33 & 73.30 \\
\hline
\end{tabular}


Table.2 Effect of weather parameters on gall weevil incidence

\begin{tabular}{|c|c|c|c|c|c|}
\hline \multirow{2}{*}{\multicolumn{2}{|c|}{$\begin{array}{l}\text { Dependent } \\
\text { variable }\end{array}$}} & \multicolumn{4}{|c|}{ Independent variable } \\
\hline & & Maximum & Minimum & Rainfall & Relative \\
\hline \multirow{2}{*}{$\begin{array}{l}\text { Incidence } \\
\text { of gall } \\
\text { weevil } \\
(\%)\end{array}$} & $\begin{array}{l}20 \\
\text { DAS }\end{array}$ & 0.441 & -0.344 & -0.658 & 0.387 \\
\hline & $\begin{array}{l}\text { 30 } \\
\text { DAS }\end{array}$ & 0.365 & -0.330 & -0.580 & 0.298 \\
\hline
\end{tabular}

The crop sown in the $2^{\text {nd }}$ fortnight showed decreased height both in healthy $(139.3 \mathrm{~cm})$ and damaged $(125.4 \mathrm{~cm})$ plants. The number of branches also decreased with 6.1 branches/plant in healthy and only 3 branches/plant in damaged plants. Yield also varied with $20.67 \mathrm{q} / \mathrm{ha}$ in healthy plant and $11.67 \mathrm{q} / \mathrm{ha}$ in damaged plants. Similar trend was followed in next sown crop and least was observed in the late sown crop during last week of August. The plant height was 94.6 $\mathrm{cm}$ in healthy plant, $66.3 \mathrm{~cm}$ in damaged plant, 3.4 branches /plant in healthy and only 1.6 branches in damaged plants. In the same way yield also varied with $0.67 \mathrm{q} / \mathrm{ha}$ in healthy plant and $0.17 \mathrm{q} / \mathrm{ha}$ in damaged plants (Fig. 1).

The study revealed that the pest attacks 15 days old redgram seedling and more severe on the delayed sown crop. The early sown crop on first week of July to last week of July suffered significantly lesser damage where in August sown crop suffered to a greater extent of damage. The results are in confirmation with the studies of Sanjay (2013) who also reported as the early stage of the crop (15 to 30 days after crop emergence) having tender stem portion was found to be critical and vulnerable for attack by gall weevil (Sanjay, 2013). This stage is preferred more may be the toughness of stem is suitable for oviposition. Increase in maximum temperature and relative humidity enhanced the incidence of gall weevil whereas the minimum temperature and rainfall was found to suppress the activity and the studies are in confirmation with the studies of Hugar (2001).

Incidence of gall weevil occurs in 15 days old plant sown from July to August. The incidence of the pest was peak in the late sown crop. Incidence of pest highly influenced by maximum temperature and relative humidity. Pest incidence affects the growth and development of the crop by damaging the early stage of the crop itself.

\section{References}

Hugar, M. B., 2001, Bioecology and management of gall weevil, Alcidodes collaris (Pascoe) on redgram. M.Sc (Agri.) Thesis, University of Agricultural sciences, Dharwad.

Panchabhavi, K.S., Thammaiah, G. and Mutalik Desai, K.S. 1972, Report on the incidence of Alcidodes collaris (Pascoe) (Curculionidae: Coleoptera) on redgram at Dharwad, Science and Culture, 38: 325-326.

Rachappa, V., Patil, R. K. and Lingappa, S., 2006, Exploitation of Metarhizium anisopliae (Metch.) Sorokin for management of gall weevil, Alcidodes collaris (Pascoe) in pigeonpea. Ann. Pl. Protec. Sci., 14(2): 315-318.

Sanjay Bandi, 2013, Studies on survey, seasonal incidence, varietal screening 
and management of major insect pests of pigeonpea in the northern transitional zone of Karnataka. Ph.D. Thesis, University of Agricultural sciences, Dharwad
Upadhyay, R., Mukerji, K.G and Rajak, R.L. 1998. IPM system in Agriculture, 4 pulses, New Delhi. p. 99.

\section{How to cite this article:}

Rakshitha, T.N., Subhash Kandakoor, M.G. Hegde and Ganajaxi Math. 2019. Effect of Different Dates of Sowing on the Incidence of Pigeonpea Gall Weevil Alcidodes collaris (Pascoe). Int.J.Curr.Microbiol.App.Sci. 8(06): 2665-2669.

doi: https://doi.org/10.20546/ijcmas.2019.806.320 